\title{
STUDI KOMPARASI HASIL BELAJAR KIMIAMENGGUNAKAN MEDIA LKM DAN TTSMELALUI IMPLEMENTASI MODEL PEMBELAJARAN KOOPERATIF SMALL GROUP DISCUSSION (SGD)
}

\author{
Henie Poerwandar Asmaningrum ${ }^{1}$ \\ ${ }^{1}$ Jurusan Pendidikan Kimia, FKIP, Universitas Musamus, Jalan Kamizaun Mopah Lama, Merauke, 99611, \\ Indonesia \\ E-mail: poerwandar@unmus.ac.id
}

\begin{abstract}
ABSTRAK
Penelitian ini bertujuan untuk mengetahui efektivitas penggunaan media Teka-Teki Silang (TTS) dibanding Lembar Kerja Mahasiswa (LKM) pada pembelajaran kooperatif Small Group Discussion (SGD) terhadap hasil belajar materi Perkembangan Teori Atom mahasiswa Jurusan Teknik Sipil Semester I Tahun Ajaran 2016/2017. Penelitian ini menggunakan metode penelitian eksperimen. Populasi dalam penelitian ini adalah semua mahasiswa Jurusan Teknik Sipil Semester I Tahun Ajaran 2016/2017. Teknik pengumpulan data dengan teknik tes, dokumentasi dan observasi. Uji prasyarat analisis untuk mengetahui apakah data berdistribusi normal atau tidak menggunakan uji normalitas. Teknik analisis data yang digunakan adalah uji t dua pihak.Hasil penelitian menunjukkan terdapat perbedaan hasil belajar Perkembangan Teori Atom mahasiswa Jurusan Teknik Sipil dimana $t_{\text {hitung }}>t_{\text {tabel }}$, yaitu 3,79>2,00. Rata-rata nilai hasil belajar dengan menggunakan media TTS adalah 81,71 dan nilai rata-rata nilai hasil belajar dengan menggunakan media LKM adalah 75,29. Kesimpulan dari penelitian ini adalah penggunaan media TTS pada model pembelajaran kooperatif SGD lebih efektif untuk meningkatkan hasil belajar mahasiswa Jurusan Teknik SipilSemester I Tahun Ajaran 2016/2017 dibanding media LKM pada materi Perkembangan Teori Atom.
\end{abstract}

Kata kunci: Komparasi, SGD, media TTS, media LKM, hasil belajar

\begin{abstract}
This research aims to determine the effectiveness of the utilization of TTS (crossword puzzle) media than LKM (student worksheet) media on the Small Group Discussion (SGD) cooperative learning on the Developments of Atomic Theory concept. This research used experimental research. The population in this study were all students of Civil Engineering Department Semester I Academic Year 2016/2017. Data collection techniques were using test engineering, documentation and observation. The prerequisite test analysis to determine distribution of data using normality test. The data analysis was usedt-test two parties technique. The results showed there are differences in learning achievement section Development of Atomic Theory of Civil Engineering Department students which is $t_{\text {count }}>t_{\text {table, }}(3,79>2,00)$. The average value by using the media TTS and LKM are 81,71 and 75,29 . As the conclusions is the use of TTS media on cooperative learning model SGD more effectively to improve achievement of Civil Engineering Department student Semester I Academic Year 2015/2016 than LKM media section Development of Atomic Theory.
\end{abstract}

Keywords: comparative, SGD, TTS media, LKM media,learning achievement DOI: http://dx.doi.org/10.15575/jta.v2i1.1364 


\section{PENDAHULUAN}

Pembelajaran kooperatif menjadi salah satu model pembelajaran yang selalu disarankan oleh hampir semua peneliti pedagogis. Bahkan telah ditunjukkan superioritas dan efektivitas pembelajaran ini dibandingkan dengan pembelajaran kompetitif dan individualistik. Tidak hanya itu, nyaris semua penelitian yang membandingkan ketiga model pembelajaran ini dan pengaruhnya terhadap prestasi belajar mahasiswa melaporkan bahwa pembelajaran kooperatif cenderung memberikan hasil belajar yang lebih baik. Uniknya, pembelajaran ini bisa diterapkan di hampir semua tingkatan umur, kelas, mata pelajaran, dan tugas akademik yang melibatkan proses berpikir tingkat tinggi, seperti pencapaian konsep, kategorisasi, pemecahan masalah secara verbal dan spasial, retensi dan daya ingat, performa motorik, prediksi, dan penilaian. Bahkan, untuk tugastugas yang bersifat hafalan maupun korektif sekalipun, pembelajaran kooperatif tidak kalah efektif dibandingkan dengan pembelajaran kompetitif dan individualistik (Johnson, 1998).

Penelitian-penelitian yang berlokasi di sekolahsekolah formal, dari TK hingga SMA, bahkan perguruan tinggi sekalipun, pada umumnya juga menunjukkan bahwa mahasiswamahasiswa yang mampu menyelesaikan tugastugas kelompok kooperatif cenderung memiliki nilai ujian akademik yang lebih tinggi, kepercayaan diri yang lebih meningkat, keterampilan sosial yang lebih mumpuni, tingkat pemahaman yang lebih besar, dan lebih jarang memberikan stereotip-stereotip buruk pada teman-temannya dibandingkan dengan mahasiswa-mahasiswa yang diajarkan dengan meto de pengajaran tradisional (Huda, 2015).

Latar belakang mahasiswa yang berada di Jurusan Teknik Sipil sangat beragam.Tidak semua mahasiswa tersebut berasal dari Jurusan IPA saat SMA. Faktor lainnya adalah kekurangaktifan mahasiswa yang terlibat dalam proses pembelajaran. Hal tersebut dapat terjadi karena model pembelajaran yang digunakan kurang melibatkan mahasiswa sebagai peserta didik secara langsung. Pembelajaran di kelas masih banyak didominasi oleh dosen sehingga kurang membangun persepsi, minat/motivasi, dan sikap peserta didik yang lebih baik. Kebanyakan peserta didik mengalami kebosanan dikarenakan model pengajaran yang berpusat pada dosen sehingga kurangnya sikap perhatian peserta didik tersebut berdampak terhadap prestasi belajar yang secara umum kurang memuaskan (Suprijono, 2010). Menurut hasil penelitian Hamdu dan Agustina diketahui bahwa satu faktor yang mempengaruhi prestasi peserta didik adalah motivasi. Dengan adanya motivasi, peserta didik akan belajar lebih keras, ulet, tekun dan memiliki konsentrasi penuh dalam proses belajar pembelajaran. Dorongan motivasi dalam belajar merupakan salah satu hal yang perlu dibangkitkan dalam upaya pembelajaran di kelas (Hamdu, 2011).

Menurut penelitian yang telah dilakukan oleh Awan, Noureen, dan Naz salah satu solusi alternatif yang dapat ditawarkan adalah pengajar harus menggunakan strategi pembelajaran inovatif dan memberikan motivasi untuk melibatkan peserta didik dalam kegiatan pembelajaran untuk meningkatkan prestasi mereka (Awan, 2011).

Dibutuhkan kepekaan dan kreativitas dosen pengampu mata kuliah Kimia Dasar agar pembelajaran dapat berjalan baik dan mampu mencapai kompetensi-kompetensi dasar yang telah ditetapkan. Salah satu model pembelajaran yang diterapkan di kelas adalah Small Group Discussion (SGD).

SGD merupakan salah satu metode pembelajaran yang paling sering diimplementasikan di dalam kelas. Kelompok diskusi ini terdiri 4 - 5 mahasiswa dan dirancang untuk mengerjakan tugas pembelajaran. Berdasarkan pengalaman, dalam kelompok ada anggota kelompok yang hanya ikut-ikutan. Hal tersebut menyebabkan beberapa mahasiswa keberatan saat dibagi 
dalam kelompok-kelompok kecil. Penentuan pemimpin kelompok disarankan, terutama yang memiliki kemampuan organisasional yang memadai. Dengan demikian diharapkan pembagian tugas antar anggota kelompok merata.

Agar hasil yang diperoleh dalam model pembelajaran SGD lebih optimal perlu adanya penunjang berupa media pembelajaran salah satunya dengan menggunakan media TekaTeki Silang (TTS) dan Lembar Kerja Mahasiswa (LKM), dengan media tersebut pembelajaran dapat lebih fokus sehingga menjadi lebih efektif dan efisien. Hal ini sesuai dengan hasil penelitian menurut Davis, Shepherd, dan Zwiefelhofer yang menyimpulkan bahwa permainan yang digunakan sebagai media pembelajaran secara langsung dapat merangsang minat siswa dan dapat menjadi teknik memotivasi yang bagus (Davis, 2009).

Media TTS dan LKM memiliki kelebihan dan kekurangan masing-masing. Dengan TTS memiliki kelebihan yaitu dapat meningkatkan motivasi mahasiswa dalam menjawab soal karena mahasiswa akan tertantang dalam menyelesaikan soal. Namun, dalam TTS ini tidak ada ringkasan materi sehingga menuntut hafalan yang tinggi dari mahasiswa. Di sisi lain, media LKM mahasiswa memiliki kesempatan untuk mengerjakan latihan soal sehingga akan memperdalam pemahaman mahasiswa, tetapi media ini memiliki kelemahan yaitu uraian materi yang singkat dapat menimbulkan miskonsepsi pada mahasiswa.

Teka-teki silang (TTS) adalah susunan kotak-kotak yang diberi nomor yang diisi dengan kata-kata, setiap kotak diisi satu huruf sehingga membentuk suatu kata yang ditempatkan secara horizontal maupun vertikal. Penggunaan teka teki silang dalam pembelajaran ini akan mengurangi rasa jenuh yang dialami mahasiswa ketika terlibat dalam proses belajar mengajar karena mahasiswa akan merasakan suasana yang berbeda ketika belajar.
Selain itu keuntungan penggunaan media TTS antara lain dapat meningkatkan motivasi mahasiswa dalam menjawab soal karena terdapat unsur permainan, dapat meningkatkan kerjasama yang sehat antar mahasiswa, dapat merangsang mahasiswa untuk berpikir kritis dan kreatif, dan dapat memacu mahasiswa untuk lebih teliti dalam mengerjakan soal (Sugiharti, 2013).

Selain memiliki kelebihan, penggunaan media TTS juga memiliki kelemahan yaitu pembuatan soal lebih sulit karena baik jawaban maupun jumlah kotak yang tersedia harus tepat. Selain itu, unsur permainan yang terkandung dalam tekateki silang akan cenderung menyebabkan suasana kelas menjadi ramai apabila dosen tidak dapat mengendalikan kelas (Suprijono, 2010).

Lembar Kerja Mahasiswa (LKM) berupa lembaran kertas yang berupa lembaran informasi maupun soal-soal (pertanyaanpertanyaan yang harus dijawab oleh mahasiswa). Dalam kegiatan belajar mengajar LKM dapat dimanfaatkan pada tahap penanaman konsep (menyampaikan konsep baru) atau pada tahap pemahaman konsep (tahap lanjutan dari penanaman konsep) karena LKM dirancang untuk membimbing mahasiswa dalam mempelajari topik.

Tujuan dan manfaat menggunakan media LKM adalah: 1) mengaktifkan peserta didik dalam mengembangkan konsep, 2) mengaktifkan peserta didik dalam proses belajar mengajar, 3) melatih peserta didik untuk menemukan dan mengembangkan ketrampilan proses, 4) membantu dosen dalam menyusun rencana pembelajaran.

Penggunaan LKM akan menimbulkan interaksi antara dosen dan mahasiswa yang akan menimbulkan kemungkinan adanya diskusi. Mahasiswa tidak hanya mendengar informasi 
dan menerima konsep dari dosen, tetapi mahasiswa dibimbing untuk menemukan suatu konsep dan mengaplikasikannya pada soal-soal yang sesuai dengan konsep tersebut. Sehingga dengan adanya soal-soal diharapkan mahasiswa dapat menguasai konsep tersebut secara mendalam.

Belajar dengan menggunakan LKM menuntut mahasiswa untuk lebih aktif, baik mental maupun fisik di dalam kegiatan belajar mengajar. Mahasiswa dibiasakan untuk berpikir kritis, logis dan sistematis, karena dituntut mencari informasi sendiri. Penggunaan LKM dapat melatih mahasiswa untuk menemukan dan mengembangkan keterampilan proses serta memberi pedoman bagi dosen dan mahasiswa dalam pencapaian pemahaman konsep (Sugiharti, 2013 dan Arikunto, 2010).

Penelitian ini bertujuan untuk membandingkan efektivitas penggunaan media TTS dengan LKM pada model pembelajaran SGD materi Perkembangan Teori Atom.

\section{METODE PENELITIAN}

Penelitian ini dilaksanakan di Universitas Musamus Merauke pada Semester I Tahun Ajaran 2016/2017, selama 2 bulan. Jenis penelitian yang digunakan adalah jenis penelitian eksperimen. Penelitian eksperimen selalu dilakukan dengan maksud untuk melihat akibat suatu perlakuan. Adapun tujuan penelitian eksperimen adalah untuk mencari hubungan sebab akibat dengan memberi perlakuan-perlakuan tertentu pada dua kelompok eksperimen, sehingga dapat diketahui perlakuan cara yang terbaik antara dua kelompok, yaitu kelompok satu (I) dan kelompok dua (II) (Arikunto, 2010).

Menurut Arikunto (2010) populasi adalah keseluruhan subjek penelitian (Arikunto, 2010). Populasi dalam penelitian ini adalahseluruh mahasiswa Jurusan Teknik Sipil Semester I Tahun Ajaran 2016/2017.
Variabel bebas dalam penelitian ini adalah media pembelajaran yang digunakan dalam model pembelajaran SGD pada materi Perkembangan Teori Atom, yaitu TTS dan LKM. Variabel terikat dalam penelitian ini adalah hasil belajar kimia.

Untuk memperoleh data digunakan metode dokumentasi, metode observasi dan metode tes. Pengumpulan data melalui metode dokumentasi dilakukan oleh peneliti guna mendapatkan data tentang nama mahasiswa dan nilai kimia pada semester akhir di SMA asal mahasiswa. Metode observasi digunakan peneliti untuk mencocokkan antara data sebenarnya dengan data yang tertulis. Sedangkan metodetes dalam penelitian ini dilakukan dengan tujuan untuk mengetahui hasil belajar kimia. Tes dilakukan pada kelas A dan kelas B. Dimana pada kelas A menggunakan media pembelajaran TTS dan kelas B menggunakan media pembelajaran LKM. Jenis tes yang digunakan dalam penelitian ini adalah tes objektif pilihan ganda sebanyak 20 soal. Tahap pertama dilakukan uji prasyarat yaitu uji normalitas. Tahap selanjutnya teknik analisis data yang digunakan untuk efektivitas penggunaan media TTS dengan LKM pada model pembelajaran SGD materi Perkembangan Teori Atom adalah dengan menggunakan uji t dua pihak.

\section{HASIL DAN PEMBAHASAN}

\section{Uji normalitas}

Uji normalitas dilakukan untuk mengkaji sampelyang diselidiki terdistribusi secara normal atau tidak. Uji normalitas dapat diketahui dengan menggunakan Chi Kuadrat. Uji normalitas menggunakan rumus $\mathrm{Chi}$ Kuadrat. Distribusi data dinyatakan normal apabila nilai Chi Kuadrat $\left(\chi^{2}\right)$ yang diperoleh $\leq$ harga Chi Kuadrat $\left(\chi^{2}\right)$ tabel dengan taraf signifikansi $5 \%$. Ringkasan hasil uji normalitas ditunjukkan pada tabel 1. 


Tabel 1. Uji normalitas nilai tes setelah
perlakuan
\begin{tabular}{|c|c|c|c|}
\hline Kelas & $\chi^{2}{ }_{\text {hitung }} \chi^{2}$ tabel & Distribusi data \\
\hline$A$ & 7,86 & \multirow{2}{*}{11,070} & Normal \\
& 6,43 & & Normal \\
\hline
\end{tabular}

Tabel 1. menunjukkan bahwa nilai $\chi^{2}$ hitung nilai tes kelas A yang menggunakan media pembelajaran TTS adalah 7,86 lebih kecil daripada $\chi_{\text {tabel }}^{2}$ pada taraf signifikansi $5 \%$ yaitu 11,070 . Hal tersebut menunjukkan bahwa data terdistribusi normal. Selain itu tabel 1 juga menunjukkan bahwa nilai $\chi^{2}$ hitung nilai tes kelas $B$ yang menggunakan media pembelajaran LKM adalah 6,43 lebih kecil dari pada $\chi^{2}$ tabel pada taraf signifikansi $5 \%$ yaitu 11,070 . Hal tersebut juga menunjukkan bahwa data terdistribusi normal.

\section{$\underline{\text { Uji Homogenitas }}$}

Uji homogenitas dilakukan untuk mengetahui apakah sampel yang diambil memiliki perbedaan varians satu sama lain. Uji homogenitas dapat diketahui dengan menggunakan uji $\mathrm{F}$ dengan melihat hasil dari signifikansi, menggunakan Pers. 1 (Arikunto, 2010)

$\mathrm{F}=\frac{\text { Varians terbesar }}{\text { Varians terkecil }}$

Apabila $F$ hitung lebih kecil dari $F$ tabel dengan signifikansi 5\%, maka data dinyatakan sama atau tidak terdapat perbedaan antar kelompok varians yang diteliti. Ringkasan hasil uji homogenitas ditunjukkan pada tabel 2.

Tabel 2. Uji homogenitas

\begin{tabular}{|l|c|c|}
\hline & Kelas A & Kelas B \\
\hline Rata-rata & 81,71 & 75,29 \\
\hline $\begin{array}{l}\text { Simpangan } \\
\text { Baku }\end{array}$ & 7,38 & 7,21 \\
\hline Varians & 59,479 & 52,013 \\
\hline F $_{\text {hitung }}$ & \multicolumn{2}{|c|}{1,14} \\
\hline Ftabel $^{|c|} 1,84$ \\
\hline Kesimpulan & \multicolumn{2}{|c|}{ Varians homogen } \\
\hline
\end{tabular}

Tabel 2 menunjukkan bahwa varians terbesar $=59,479$ dan varians terkecil $=52,013$. Jadi $\mathrm{F}_{\text {hitung }}=59,479: 52,013=1,14$. Harga $F_{\text {hitung }}$ tersebut kemudian dibandingkan dengan $F_{\text {tabel }}$ yaitu 1,84 (dengan dk pembilang dan penyebut masing-masing 30) kemudian dengan taraf kesalahan $5 \%$. Karena harga $F_{\text {hitung }}$ lebih kecil dari $F_{\text {tabel }}(1,14<1,84)$ maka dapat disimpulkan bahwa varians homogen.

\section{Penquiian Hipotesis}

Hipotesis merupakan jawaban sementara atas permasalahan yang dirumuskan, oleh sebab itu jawaban sementara itu harus diuji kebenarannya secara empirik. Setelah uji prasyarat dan asumsi telah terpenuhi, maka selanjutnya dilakukan pengujian hipotesis menggunakan uji t dengan $\mathrm{H}_{0}$ : tidak ada perbedaan hasil belajar kimia mahasiswa Jurusan Teknik Sipil Semester I Tahun Ajaran 2016/2017 melalui implementasi metode pembelajaran kooperatif SGD menggunakan media TTS dengan media LKM, dan $\mathrm{H}_{1}$ : ada perbedaan hasil belajar kimia mahasiswa Jurusan Teknik Sipil Semester I Tahun Ajaran 2016/2017 melalui implementasi metode pembelajaran kooperatif SGD menggunakan media TTS dengan media LKM

Uji t dihitung menggunakan Pers. 2:

$$
\mathrm{t}=\frac{\overline{x_{1}}-\overline{x_{2}}}{\sqrt{\frac{s_{1}^{2}}{n_{1}}+\frac{s_{2}^{2}}{n_{2}}}}
$$

Hasil perhitungan menunjukan bahwa harga $t_{\text {hitung }}=3,79$. Kemudian harga $t_{\text {hitung }}$ dibandingkan tabel untuk mengetahui apakah $\mathrm{H}_{0}$ diterima atau ditolak. Harga $\mathrm{t}_{\text {tabel }}$ didapatkan $\mathrm{dk}=60$ yaitu 2,00 dengan taraf kesalahan $5 \%$. Karena harga $t_{\text {hitung }}$ lebih besar dari $t_{\text {tabel }}(3,79$ $<2,00$ ), maka $\mathrm{H}_{0}$ ditolak sehingga dapat disimpulkan bahwa ada perbedaan hasil belajar kimia mahasiswa Jurusan Teknik Sipil Semester I Tahun Ajaran 2016/2017 melalui implementasi metode pembelajaran kooperatif SGD menggunakan media LKM dengan media TTS. 
Ada beberapa elemen dasar yang membuat pembelajaran kooperatif lebih produktif dibandingkan dengan pembelajaran kompetitif dan individual. Salah satunya adalah pemrosesan kelompok. Kerja kelompok yang efektif biasanya dipengaruhi oleh sejauh mana kelompok tersebut merefleksikan proses kerjasama mereka. Dalam pembelajaran kooperatif, pemrosesan kelompok dapat didefinisikan sebagai refleksi kelompok dalam mendeskripsikan tindakan apa saja yang membantu dan tidak terlalu membantu serta membuat keputusan tentang tindakan apa saja yang dapat dilanjutkan atau perlu diubah. Tujuan pemrosesan kelompok adalah mengklarifikasi dan meningkatkan efektivitas kerjasama antar anggota untuk mencapai tujuan kelompok (Huda, 2015).

Dalam penelitian ini, diskusi yang dilakukan oleh kelompok-kelompok berjalan baik. Setiap anggota kelompok melakukan bagiannya masing-masing. Saat pembagian TTS di kelas A diskusi yang telah berjalan baik semakin tinggi tingkat antusias menya karena ketertarikan dan penasaran dalam menyelesaikan soal. Interaksi antar anggota kelompok berjalan lebih baik dan positif, misalnya saat kelompok merasa telah menemukan jawaban, namun setelah dicocokkan ternyata jumlah kotak tidak sesuai. Atau saat jawaban yang ditemukan sesuai dengan jumlah kotak yang disediakan.

Hal berbeda diamati pada kelas B, tidak ada perubahan antusiasme yang berarti. Hal ini disebabkan karena konten LKM kurang lebih sama dengan konten LKS yang telah diterima sejak masa sekolah dulu. Sehingga mahasiswa telah terbiasa dalam menggunakan LKM. Tidak ada ukuran atau batasan saat mengisikan jawaban, sehingga mahasiswa hanya menjawab sebatas pemahamannya saja.

Hasil ini sejalan dengan penelitian Sugiharti $S$, dkk (2013) di mana penelitian tersebut menunjukkan bahwa penggunaan media TTS lebih efektif dibandingkan media LKS pada pembelajaran kooperatif STAD terhadap prestasi belajar SPU siswa kelas X SMA N 1 Karanganyar semester I tahun pelajaran 2012/2013. Hal tersebut dibuktikan dengan : (1) prestasi belajar kognitif siswa pada penggunaan media TTS $(44,706)$ lebih tinggi dibanding media LKS $(40,353)$ pada pembelajaran kooperatif STAD materi SPU, (2) prestasi belajar afektif siswa pada penggunaan media TTS $(91,118)$ lebih tinggi dibanding media LKS $(86,147)$ pada pembelajaran koo peratif STAD materi SPU (Sugiharti, 2013).

Demikian juga hasil penelitian Rakhmadhani, N., dkk (2013) yang menunjukkan bahwa terdapat pengaruh signifikan dalam penerapan metode TGT berbantuan media TTS (kelas eksperimen I) dan ular tangga (kelas eksperimen II) pada pembelajaran materi koloid terhadap prestasi belajar kimia di SMA Negeri 1 Simo. Dimana selisih nilai kognitif pada kelas eksperimen I lebih baik daripada kelas eksperimen II dan hasil analisa statistik diperoleh nilai signifikansi $(\rho)$ sebesar $0,(\rho)<$ 0,05 (Rakhmadhani, 2013).

Peranan penggunaan media dalam proses belajar mengajar dapat membangkitkan keinginan/minat yang baru, membangkitkan motivasi, rangsangan untuk belajar, dan membawa pengaruh psikologis terhadap peserta didik. Penggunaan media pembelajaran pada tahap orientasi pembelajaran akan sangat membantu keefektifan proses pembelajaran dan penyampaian pesan dari isi pelajaran yang diberikan (Arsyad, 2009).

\section{KESIMPULAN}

Berdasarkan hasil penelitian dapat disimpulkan bahwa penggunaan media TTS pada pembelajaran kooperatif Small Group Discussion (SGD) lebih efektif untuk meningkatkan hasil belajar mahasiswa Jurusan Teknik Sipil Semester I Tahun Ajaran 2016/2017 dibandingkan dengan menggunakan media LKM pada materi Perkembangan Teori Atom. Hal ini terbukti dari nilai rata-rata hasil belajar kelas yang menggunakan media TTS lebih baik 
daripada kelas yang menggunakan media LKM $(81,71>75,29)$. Hasil tersebut didukung oleh hasil uji $t$ dua pihak dimana harga $t_{\text {hitung }}(3,79)$ lebih besar dari $t_{\text {tabel }}(2,00)$.Yang artinya ada perbedaan hasil belajar kimia mahasiswa Jurusan Teknik Sipil Semester I Tahun Ajaran 2016/2017 melalui implementasi metode pembelajaran kooperatif SGD menggunakan media TTS dengan media LKM.

\section{DAFTAR PUSTAKA}

Arikunto, S. (2010). Prosedur Penelitian Suatu Pendekatan Praktik. Jakarta : PT Rineka Cipta.

Arsyad, A. (2009). Media Pembelajaran., Jakarta: Rajawali Persada.

Awan, R.U.N., Noureen, G., \& Naz, A.(2011). Journal International Education Studies, $4(3), 72-79$.

Davis, T.M., Shepherd, B., Zwiefelhofer T. (2009). Reviewing for Exams : Do Crossword Puzzles Help in the Success of Student Learning? The Journal of Effective Teaching, 9(3),4-10.

Hamdu, G. dan Agustina, L.(2011). Jurnal Penelitian Pendidikan, 12(1), 90-96.

Huda, M. (2015). Cooperative Learning : Metode, Teknik, Struktur, dan Model Penerapan. Yogyakarta : Pustaka Pelajar.

Johnson, D.W., Johnson, R.T., \&Smith, K.A. (1998). "Maximizing Instruction through Cooperative Learning.'ASEE Prism. 7(6), 24-29.

Rakhmadhani, N., Yamtinah, S., \&Utomo, S. B. (2013). Pengaruh Penggunaan Metode Teams Games Tournaments Berbantuan Media Teka-Teki Silang dan Ular Tangga dengan Motivasi Belajar terhadap Prestasi Belajar Siswa pada Materi Koloid Kelas XI SMA Negeri 1 SImo Tahun Pelajaran
2011/2012. Jurnal Pendidikan Kimia, 2(4), 190-197.

Suprijono, A. (2010). Cooperative Learning, Yogyakarta: Pustaka Belajar.

Sugiharti, S., Saputro, S.,\& Sugiharto. (2013). Studi Komparasi Penggunaan Media TTS dan LKS Pada Pembelajaran Kooperatif Student Teams Achievement Divisions (STAD) Pada Materi Pokok Sistem Periodik Unsur Kelas X Semester Gasal SMA Negeri I Karanganyar Tahun Pelajaran 2012/2013. Jurnal Pendidikan Kimia, 2(1), 73-79. 